
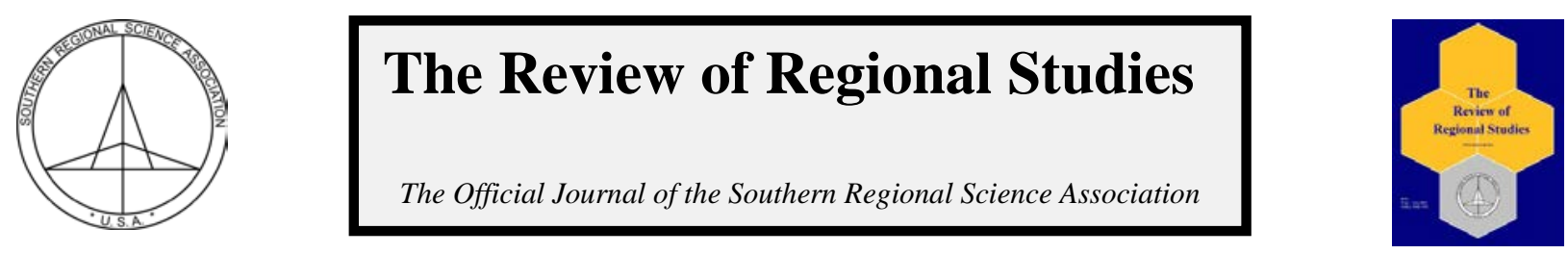

\title{
Economic Impact of a Heritage Policy on Residential Property Values in a Historic District Context: The Case of the Old City of Quebec
}

\author{
Nicolas Devaux ${ }^{\mathrm{a}}$, Etienne Berthold ${ }^{\mathrm{b}}$, and Jean Dubéc \\ ${ }^{a}$ Department of Societies, Territories, and Development, University of Quebec in Rimouski, Canada \\ ${ }^{b}$ Department of Geography, Laval University, Canada \\ c School of Planning and Development, Laval University, Canada
}

\begin{abstract}
Previous studies have attempted to measure the willingness-to-pay to locate inside a historic district. Yet not enough attention has been paid to the implicit value attributed to the impact of heritage policies within the historic district. This paper fills that gap by investigating the impact of such policies on individual condominium properties for the case of the Old City of Quebec (Canada), designated by law as a protected area and included on the World Heritage List (UNESCO). More precisely, this research measures the impacts of the reorganization and landscaping of one particular street located south-west of the protection area in the old part of Quebec City. A difference-in-differences (DID) estimator based on a hedonic repeated sales approach is proposed to isolate such effects based on proximity to the site under study. Estimation results suggest that the reorganization of the street had no significant impact on the closest properties' prices, but had negative effects for properties located within 150 to 450 meters of the street. These observations outline complex relations between heritage policies and urban landscaping projects.
\end{abstract}

Keywords: historic districts, landscaping policy, urban policy, hedonic pricing model, urban regeneration JEL Codes: O18, R31, R52, R58

\section{INTRODUCTION}

Cultural heritage has gained more importance in the field of urban studies (Harrison, 2013). Public policies are an essential part of heritage conservation that protect the history of an area (Graham, Ashworth, and Tunbridge, 2000; Saint-Pierre, 2008). As with many cultural policies, heritage policies may produce cultural benefits for local communities and nations, among which collective identity flourishes (Hobsbawm and Ranger, 1983; Harrison, 2013). Urban heritage policies should be distinguished from a standard landscaping policy because they include intangible and symbolic goals.

Such policies can also have important economic effects. Such impacts can be expressed through economic benefits related to increased tourism, but also through externalities for residents and commercial businesses. For the former, the classical input-output analysis is used to evaluate the direct, indirect, and spinoff effects. For the latter, hedonic modeling has proved to be an elegant way of measuring the implicit price (or willingness-to-pay) of being close to such

Nicolas Devaux (Department of Societies, Territories, and Development) is Professor at Universtiy of Quebec in Rimouski, Rimouski, Qc, Canada. Etienne Berthold (Department of Geography) and Jean Dubé (School of Planning and Development) are Professors at Laval University, Quebec City, Qc, Canada. Corresponding Author: N. Devaux E-mail: Nicolas.devaux@uqar.ca

(c) Southern Regional Science Association 2018.

ISSN 1553-0892, 0048-749X (online)

www.srsa.org/rrs 
(urban) externalities. So far, willingness-to-pay has been limited to residential property values with emphasis on the impact of being inside a historic district designation on property values (Clark and Herrin, 1997; Leichenko, Coulson, and Listokin, 2001; Mason, 2005; Narwold, Sandy, and Tu, 2008; Ryberg-Webster and Kinahan, 2014). If designation (protecting a specific zone) is a necessary condition to preserve historical fashion, it is not a sufficient condition to ensure cultural and ideological symbolism of the area. The implicit market value to locate inside designation zoning can spatially evolve over time depending on punctual development/heritage policies in a given area. However, such a possibility remains unclear, since existing approaches neglect the impact of potential heritage policies within the historic designation, which are multifold.

This paper investigates the impacts of a particular heritage policy on residential (condominiums) values in a historic district context. While positive economic impacts are expected, there is still a possibility that negative externalities related to a heritage landscape policy, such as additional crowding and noise, dominate. In such a case, the net impact for the resident could be negative. A negative effect should then not be considered as a global negative effect, but instead as a price paid by residents to achieve global success for a policy's symbolic objectives. We base the analysis on the case of the Old City of Quebec (Canada), the oldest part of the oldest city in Canada. The research aims to assess the effect of a particular heritage policy, as a part of a wider set of interventions in the context of an urban regeneration project, focusing on historic building restoration. A difference-in-differences (DID) estimator based on a repeated sales approach (Dubé et al., 2011, 2013) is applied to assess the impact of an exogenous landscaping policy (the Auteuil Street restoration) using a sample of 744 condominium pairs of transactions within the old part of the city between 1997 and 2011. In the dense context of a historic district, the definition of proximity can affect study results. Consequently, Euclidean and the network distance are used to compare the local impact of proximity to historical heritage restoration work on residential real estate values. Results show no significant impact for the properties located close to the site, but the reorganization of the street had a negative and significant effect on sale prices for properties located a little further from the street. Results outline possible complex relations between the heritage policy and urban landscaping projects. Since heritage in a historic district is not set, the meanings given to the historic district can change through the years as well as the impact of heritage policies and their diffusion over space.

The paper has five remaining sections. The next section highlights the role of cultural heritage and heritage policies. This section also attempts to summarize and discuss research that has addressed the impacts of a historic designation on real estate values. The third section formally presents the methodological approach used in the paper. The fourth section introduces the Old City of Québec and the case under study (the restoration of d'Auteuil Street), as well as the data used to estimate the model, while the fifth section discusses the main findings. The final section proposes a brief discussion and a conclusion.

\section{HERITAGE POLICIES AND HEDONIC MODELING OF RESIDENTIAL PROPERTY VALUES IN HISTORIC DISTRICTS}

Urban regeneration projects focusing on restoration and historic building development are now at the forefront of policy (Harrison, 2013). Cultural heritage may be defined as an object, a collection, or an intangible heritage that has been judged worthy to be preserved, passed on, and put on display. Heritage is a search for a form of meaning and is part of a system defined 
by its capacity to create signs, a system upheld by institutions, standards, practices, values, and symbols (Morisset, 2009). Heritage also concerns political terms, often in ways that seek to legitimize power (Hobsbawm and Ranger, 1983). As with many cultural policies (Saint-Pierre, 2008), heritage policies do not follow a static list of objectives. They reflect the historic contexts in which they were created. They carry the speeches that a given society holds on its heritage at a given moment in its history. As shown by Foucault (1969), discourses embody in discursive practices through which cultural meanings are produced in relevance with political ideologies (Graham, Ashworth, and Tunbridge, 2000), knowledge constructs (Berthold, 2012a), as well as economic influences (Zukin, 1996). Consequently, the development of heritage policies is ever changing through space and time. Thus, urban planning in a historic district takes on a new meaning and dimension, playing an important role in heritage construction using symbolism and ideologies. One important question is whether such discursive objectives, sought through preservation, also turn into economic impacts?

The economic impacts of heritage policies are multifold. Heritage policies may produce cultural benefits, such as collective identity development and social cohesion, for local communities and nations (Hobsbawm and Ranger, 1983; Harrison, 2013). There are at least two complementary ways to approach the economic impacts of heritage policies. On the one hand, heritage is frequently regarded from the viewpoint of tourism benefits producing economic spinoffs. From this perspective, the emphasis is placed on the multiplicative (direct, indirect and induced) economic benefits of tourism on local economic activities as well as on fiscal impacts (Greffe, 2003). On the other hand, some attempts have been made to measure the economic impact of historic designation (Mason, 2005) through real estate values (Clark and Herrin, 1997; Leichenko, Coulson, and Listokin, 2001; Narwold, Sandy, and Tu, 2008). However, to our knowledge, few empirical studies have attempted to assess the economic effect of a particular landscaping heritage policy on property values in a historic district context.

Heritage policies must be seen as generating externalities internalized through the real estate market, implying that it may be possible to recover its implicit price through a hedonic pricing model. As underlined by the hedonic theory (Rosen, 1974), property values are expected to be related to urban externalities such as landscaping. Urban green space and tree cover projects have a positive impact on property values (Sander, Polasky, and Haight, 2010; Roy, 2012). However, the heritage policies and urban reorganization is not limited to green space. As a part of a patrimonialization project, the associated heritage policy having a cultural and symbolic dimension is desired. Heintzelman and Altieri (2013) found that if benefits associated with the creation of a historic district result in a positive effect on prices, they can be overwhelmed by the negative effects of the associated restrictions. As such, there is "a need for more empirical studies on the contemporary relationship between preservation and urban revitalization and planning” (Ryberg-Webster and Kinahan, 2014, p. 123).

The historic designation is expected to have positive impacts on property values by increasing neighborhood prestige and neighborhood social capital, or by providing protection from construction projects (Rickman, 2009). Narwold, Sandy, and Tu (2008) studied the case of San Diego (CA) and found a 16 percent premium on house prices, while Clark and Herrin (1997) and Leichenko, Coulson, and Listokin (2001) also noted higher property values, respectively for Californian and Texan case studies. Similar observations have been made by Asabere and Huffman (1991) in Philadelphia (PA) and by Coulson and Leichenko (2001) in Abilene (TX). 
The impact can vary according to the type of properties (Zahirovic-Herbert and Chatterjee, 2012) and the architectural style (Asabere, Huffman, and Mehdian, 1997).

Beyond being located inside a historic district, proximity to historical sites of interest may be of importance as well and motivate a higher willingness-to-pay for such locations. Moro et al. (2013) observed that distance to cultural heritage sites positively influences housing prices in Dublin (Ireland). Van Duijn and Rouwendal (2013) observed that proximity to cultural heritage sites is particularly valued by wealthier households. Lazrak et al. (2014) attempted to measure such intangible heritage factors by assessing the effect of listed buildings on market price. Their results show a 26.9 percent increase for a listed building's price and a 0.28 percent average increase for the prices of the surrounding buildings in a 50-meter radius. Coffin (1989) found results pointing in the same direction, but with a modest effect that can even lead to a reduction in house prices.

Of course, designation is an important part of heritage policies, though by no means is it the only heritage policy at work in a historic district (Berthold, 2012a). Only Noonan (2007) and Leichenko, Coulson, and Listokin, (2001) have introduced this pattern, measuring the impacts of a private property historic designation on hedonic modeling. Conclusions suggest a positive, and in most cases significant, effect on house prices. In both cases, the way the historic dimension is expressed in the independent variables can be perfected: it neglects the possibility that the effect may well depend on punctual urban landscaping policies since "the totality of the built environment [...] constitutes the amenity recognized by real estate markets” (Ahlfeldt and Meannig, 2010, p. 314).

Despite the contribution of punctual heritage policies, to our knowledge, no previous work has attempted to assess how housing values react to an urban development project in the context of a historic district. According to previous studies' conclusions, if the considered heritage policies successfully managed to become the place of commemoration and the cultural symbol, positive impacts on property values are expected. Nevertheless, the reduction in the number of parking places as well as the retraction of the street to the benefit of a paved one-way traffic street could also have negative effects for the residents. As such, the aim of the paper is to investigate the effect of a particular heritage policy through modification in landscaping inside the historic designated district.

\section{METHODOLOGICAL FRAMEWORK}

Hedonic theory (Rosen, 1974) suggests that the price of a complex good can be expressed as a function of the various attributes forming the bundle. Hedonic modeling is appropriate for cross-sectional analyses (Gibbons and Machin, 2008) and is applied in the real estate literature. In a multiple linear regression framework, this means that each coefficient related to a given characteristic represents its implicit (hedonic) price. In the case of housing, many amenities, both intrinsic and extrinsic to the property, are proven to have a significant influence on the determination of the market value of units.

In such a case, the sale price of a real estate good $j$ sold at time period $t$ is represented by a vector $p_{j t}$. In order to control for heteroskedasticity issues and to ensure that the dependent variable is normally distributed, it is common practice to express the sale price using a logarithmic transformation (Dubé et al., 2011). The sale price is expressed as a function of a set of intrinsic and extrinsic amenities. These amenities are considered through matrices $\boldsymbol{X}_{j t}$ and $\boldsymbol{Z}_{j t}$, 
respectively. Since real estate prices may be influenced by temporal market fluctuations and price evolution, a matrix, $\boldsymbol{D}_{j t}$, composed of a set of temporal dummy variables, accounts for the nominal aspect of prices. This gives us the following equation:

$$
\boldsymbol{p}_{j t}=\iota \alpha+\boldsymbol{D}_{j t} \boldsymbol{\delta}+\boldsymbol{X}_{j t} \boldsymbol{\beta}+\boldsymbol{Z}_{j t} \boldsymbol{\theta}+\boldsymbol{u}_{j t}
$$

where $\boldsymbol{\beta}$ and $\boldsymbol{\theta}$ are the vectors of parameters of interest (the hedonic prices), while the vector of parameters, $\boldsymbol{\delta}$, controls for the nominal aspect of the final sale price. The parameter $\alpha$ refers to the constant term of the equation. The vector $\boldsymbol{\iota}$ is composed of a series of ones (i.e., the constant terms), and $\boldsymbol{u}_{j t}$ is the usual vector of error terms.

Since heritage policy is assumed to impact changes in implicit price (before and after), the parameters associated with the proximity of the place where historical landscaping policy occurs is assumed to change over time. As such, a set of dummy variables, $\boldsymbol{R}_{\boldsymbol{j} \boldsymbol{t}}$ are included to control for the distance between a given good, $j$, and the place where the change occurs. A set of coefficients for these variables is assumed to be different before, $\boldsymbol{\varphi}_{\boldsymbol{b}}$, and after, $\boldsymbol{\varphi}_{\boldsymbol{a}}$, the landscaping change:

$$
\boldsymbol{p}_{j t}=\iota \alpha+\boldsymbol{D}_{j t} \boldsymbol{\delta}+\boldsymbol{X}_{j t} \boldsymbol{\beta}+\boldsymbol{Z}_{j t} \boldsymbol{\theta}+\boldsymbol{R}_{j t} \boldsymbol{\varphi}_{\boldsymbol{b}}+\boldsymbol{R}_{j t} \boldsymbol{\varphi}_{\boldsymbol{a}}+\boldsymbol{u}_{j t}
$$

In the current case, four different distance buffers, based on Euclidean buffers, are considered within 0 to 600 meters, with the over 600 meters as the reference group. ${ }^{1}$ The distance buffers are used in order to correspond to the spatial distribution of the observations and guarantee statistical significance of the results.

The validity of the estimated parameters, $\boldsymbol{\varphi}_{\boldsymbol{b}}$ and $\boldsymbol{\varphi}_{\boldsymbol{a}}$, depends on some crucial assumptions (Dubé and Legros, 2014). One of these assumptions is that all significant amenities are included in the price equation. Otherwise, the coefficients can suffer from omitted variable bias. However, it is almost impossible to make sure that no important variables are missing. A simple and elegant way to control for such bias is to use a first difference transformation.

The repeated sales approach is based on transactions of a given good that appears at least twice over the time period under consideration. This transformation reduces the sample size from $N_{T}$ to $n_{T}$, with $n_{T} \ll N_{T}$. Denoting by $s$ the moment of the first transaction (sold), by $r$ the moment of the second transaction (resale), and taking the first difference between the price equation at each moment returns the final equation to be estimated using the repeated sales approach:

$$
\begin{aligned}
\left(\boldsymbol{p}_{j r}-\right. & \left.\boldsymbol{p}_{j s}\right)=\left(\boldsymbol{\iota} \alpha_{r}-\boldsymbol{\iota} \alpha_{s}\right)+\left(\boldsymbol{D}_{j r}-\boldsymbol{D}_{j s}\right) \boldsymbol{\delta}+\left(\boldsymbol{X}_{j r}-\boldsymbol{X}_{j s}\right) \boldsymbol{\beta} \\
& +\left(\boldsymbol{Z}_{j s}-\boldsymbol{Z}_{j r}\right) \boldsymbol{\theta}+\boldsymbol{R}_{j}\left(\boldsymbol{\varphi}_{\boldsymbol{b}}+\boldsymbol{\varphi}_{\boldsymbol{a}}\right)+\left(\boldsymbol{u}_{j r}-\boldsymbol{u}_{j s}\right)
\end{aligned}
$$

where, by construction, $\boldsymbol{R}_{j t}=\boldsymbol{R}_{j r}=\boldsymbol{R}_{j s}=\boldsymbol{R}_{j}$. Equation (3) can be simplified since the new independent variable expresses the difference within the amenities regarding the moment of the transaction, assuming that the implicit price of other amenities is constant over time:

$$
\Delta \boldsymbol{p}_{j}=\Delta \boldsymbol{D}_{j} \boldsymbol{\delta}+\Delta \boldsymbol{X}_{j} \boldsymbol{\beta}+\Delta \boldsymbol{Z}_{j} \boldsymbol{\theta}+\boldsymbol{R}_{j}\left(\boldsymbol{\varphi}_{\boldsymbol{b}}+\boldsymbol{\varphi}_{\boldsymbol{a}}\right)+\boldsymbol{\varepsilon}_{\boldsymbol{j}}
$$

$\left(\varphi_{b}+\varphi_{a}\right)$ represents the difference in the willingness-to-pay to be located close to the street after a given change to the historic landscape.

\footnotetext{
${ }^{1}$ Tests were performed in order to define the buffer distance and the 600 meter threshold.
} 
The repeated sales approach produces a difference-in-differences (DID) estimator that is based on three assumptions. First, the good's sales frequency follows a random process, meaning that no particular factor can explain why a good is sold more often than another (Gatzlaff and Haurin, 1997, 1998). Second, if no particular information is available, the amenities of the real estate goods are assumed to be constant. Otherwise, the change in the amenities is captured and included in the equation through the matrices $\Delta \boldsymbol{X}_{j}$ and $\Delta \boldsymbol{Z}_{j}$ (Dubé et al., 2013). Finally, the specification assumes that the coefficients are constant over time (Case and Schiller, 1987, 1989).

The DID estimator in a repeated sales approach has the advantage of cancelling the effect of constant elements, such as other spatial amenities (shops, other historic sites, etc.) or unit characteristics, assuming that they are stable over time. Assuming that the d'Auteuil Street renovation is part of an urban development policy decided and implemented independently of the economic agents (residential real estate buyers and sellers), the modification can be considered exogenous, at least from the perspective of agents, sellers, and buyers (Gibbons and Machin, 2008; Dubé et al., 2011). Moreover, residuals from the hedonic pricing model are known to be spatially autocorrelated, which violates one of the assumptions of the ordinary least squares (OLS) approach and results in imprecise estimators and variance. However, such a spatial autocorrelation problem can be managed with the DID transformation if the pattern is created by a misspecification of the original functional form (McMillen, 2010) or by spatial omitted variables issues (Dubé et al., 2011).

\section{EMPIRICAL APPLICATION}

\subsection{The Old City of Quebec Historic District and the Reorganization of d'Auteuil Street as Heritage Policies}

The Old City of Quebec is at the heart of important heritage policies, as the City of Quebec itself is one of the ancient cities in North America (founded in 1608). Thus, the historic district is particularly well adapted to measure the possible economic effects of heritage policies. The Old City of Quebec has been a historic designated district since 1963 . It comprises $3.5 \mathrm{~km}^{2}$ stretching from Champlain Street to St. Vallier Street East in the Lower Town and the walled city as well as Côte d'Abraham in the Upper Town. According to the 2011 census, its population was 4,780 inhabitants, and there were major socio-economic disparities among its different sectors.

The Old City is characterized by a concentration of shops and jobs. In 2010, about 15,000 people entered the district to work every day, and the traffic flow was around 30,000 vehicles per weekday, most of them in transit (i.e., they did not originate in the Old City and were headed elsewhere). Moreover, tourism in the Old City has risen since 1985 when UNESCO listed Quebec City as a world heritage site. Approximately 4,013,000 people visited in 2008, according to Office du Tourisme estimates (Berthold, 2010).

A decisive and significant heritage policy in the Old City was the restoration of Place Royale, conducted by the Quebec government in the 1970s to recall the birthplace of New France (Berthold, 2012b). The reorganization and landscaping of d'Auteuil Street took place by the mid-2000s from a different heritage policy. 
Figure 1: D’Auteuil Street Before and After Restoration

Figure 1a. The Old d'Auteuil Street

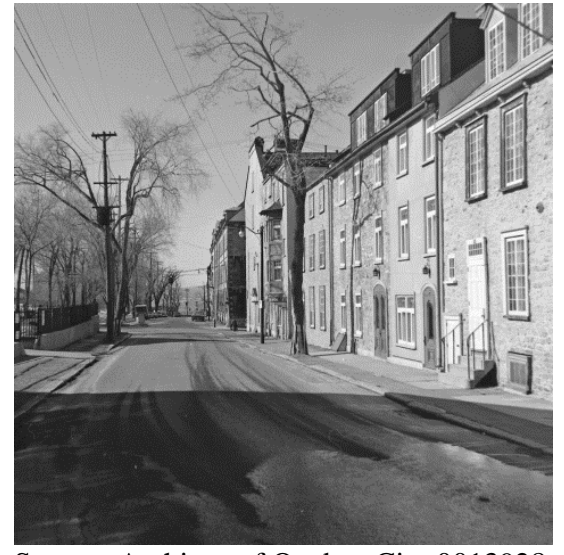

Source: Archives of Quebec City 0013928
Figure 1b. The New d'Auteuil Street

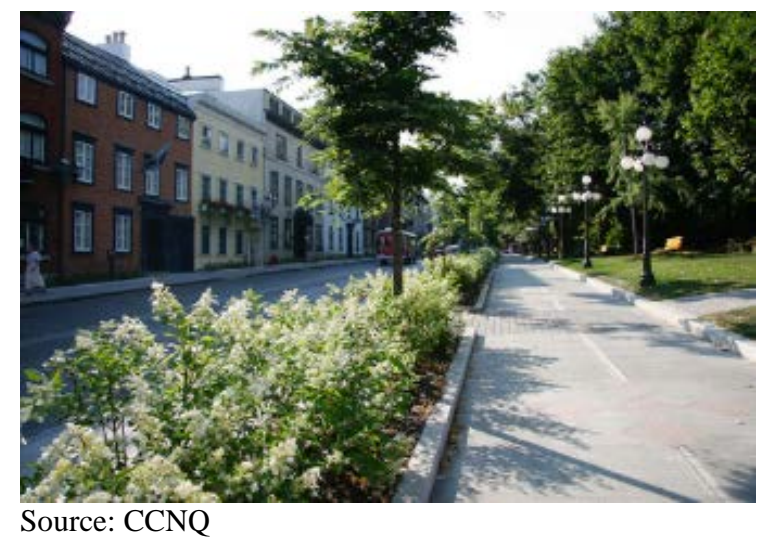

Figure 1c. Monuments Dedicated to Foreign Poets

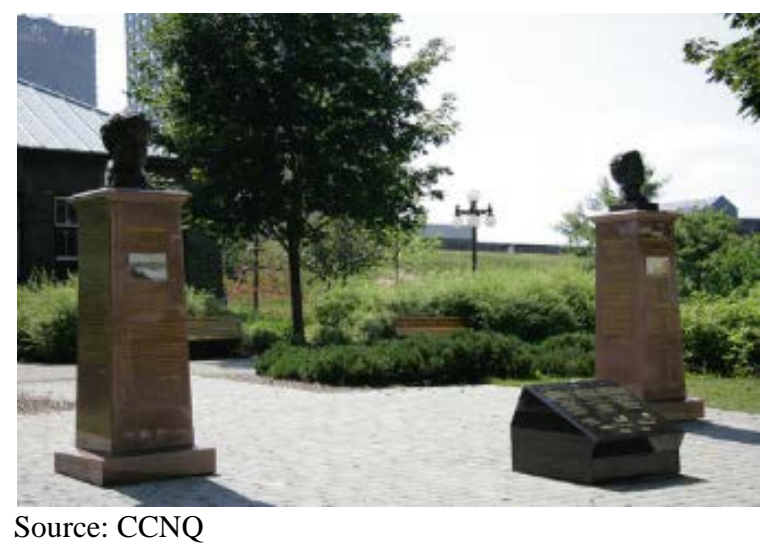

By the end of the 1990s to the present day, historic commemoration and cultural heritage management in the Old City of Quebec historic district has been partly conducted through the Commission de la Capitale Nationale du Québec (CCNQ). This organization was created in the mid-1990s by the Parti Québécois nationalistic government. It was given a threefold mandate. First, to reorganize the parliament hill, on which sits the Quebec National Assembly. Second, to promote Quebec national history through the historic commemoration of great men and celebrities. Finally, to promote internationally the city of Quebec as Quebec's national capital city, though in fact Canada's capital city is Ottawa. One way to do so was the commemoration of monarchs and other great men from all around the world. The reorganization and landscaping of d'Auteuil Street, to which we now shall turn, was deeply influenced by such heritage policy.

D'Auteuil Street is one of a hundred streets that can be found in the Old City of Quebec. It is located south-west of the historic district. It houses about 30 buildings, most of which are condominiums, rental apartments and offices. The street itself was settled mostly from the mid$19^{\text {th }}$ century by bourgeois citizens. By the summer of 2005, d'Auteuil Street was reorganized and landscaped following an agreement between the CCNQ and Quebec's city council. This reorganization was conducted in two main streams. First, it comprised various measures regarding urbanism. Among them was the reorganization of the traffic into a one-way street 
Table 1: Temporal Distribution of the Transactions

\begin{tabular}{|c|c|c|c|c|c|c|}
\hline & \multicolumn{3}{|c|}{ Sale Price } & \multicolumn{3}{|c|}{ Resale Price } \\
\hline & Transactions & Mean & Std. Dev. & Transactions & Mean & Std. Dev. \\
\hline 1997 & 34 & 113893.6 & 75708.6 & 1 & 89466.7 & 37302.19 \\
\hline 1998 & 98 & 93645.9 & 51698.1 & 25 & 101119.0 & 68257.2 \\
\hline 1999 & 77 & 99782.1 & 72701.7 & 22 & 96140.4 & 64781.8 \\
\hline 2000 & 54 & 94260.7 & 45620.8 & 27 & 95881.5 & 37339.0 \\
\hline 2001 & 90 & 108993.5 & 74126.1 & 45 & 91278.7 & 35206.3 \\
\hline 2002 & 65 & 116412.8 & 63598.4 & 48 & 116019.2 & 76254.2 \\
\hline 2003 & 81 & 153670.2 & 72315.7 & 56 & 147042.3 & 83906.2 \\
\hline 2004 & 82 & 163358.6 & 70419.7 & 74 & 153439.2 & 71049.4 \\
\hline 2005 & 57 & 171928.7 & 74616.1 & 84 & 177085.6 & 73810.1 \\
\hline 2006 & 33 & 162166.7 & 72012.3 & 52 & 186351.3 & 88012.3 \\
\hline 2007 & 27 & 194854.9 & 97539.7 & 58 & 216689.6 & 103985.3 \\
\hline 2008 & 22 & 204240.5 & 60760.8 & 70 & 206222.8 & 75429.5 \\
\hline 2009 & 21 & 182160.7 & 48694.2 & 71 & 237587.6 & 99944.7 \\
\hline 2010 & 2 & 390000.0 & 21213.2 & 82 & 255417.5 & 93022.5 \\
\hline 2011 & 1 & 151000.0 & - & 27 & 237461.2 & 87128.2 \\
\hline Overall & 744 & 132666.8 & 76966.91 & 744 & 178170.8 & 96251.24 \\
\hline
\end{tabular}

leading south of the historic district. At the same time, the road was narrowed into a two-lane road instead of four before the reorganization occurred. Second, the landscaping of the street was underlined by a heritage policy. Some work was done to replace asphalt by a traditional paved road. Sidewalks were enlarged and decorated with plants and other vegetal species. Finally, but not least, monuments dedicated to foreign poets such as Alexander Pushkin, Dante Alighieri, and Komitas were installed. Such heritage policy mirrored the wish to underline the international character of Quebec City according to the CCNQ's mission (see Figure 1). ${ }^{2}$

\subsection{Transaction data}

The dataset was transmitted by the real estate valuation service of the City of Quebec and collected using the land register of the Province of Quebec. ${ }^{3}$ It originally consists of 1,631 condominium sales occurring between 1997 and 2011. A few transactions are discarded to ensure that the sale price and the exact location of the transactions is available. After discarding some transactions due to missing or imprecise information, the final dataset consists of 1,477 transactions from which 744 repeated sales are identified and compose the final sample. The mean sale price is $\mathrm{CAD} \$ 132,666$ while the mean resale price is CAD $\$ 178,170$, which corresponds to a 34 percent increase of the mean nominal prices (Table 1).

Using the geographical coordinates of each transaction, a total of 97 different buildings are identified (same pairs of coordinates). The transactions occur in some buildings spatially concentrated within the walls of the Old City (Figure 2), while the small number of independent buildings where transactions occur suggests that many transactions are located in the same

\footnotetext{
${ }^{2}$ http://www.capitale.gouv.qc.ca/realisations/voies-d-acces/rue-d-auteuil (accessed in August, 2016).

${ }^{3}$ After estimations, the transaction price index’s progression corresponds to that observed for the entire Quebec City region.

(c) Southern Regional Science Association 2018.
} 


\section{Figure 2: Spatial Distribution of the Repeated Sales in Old Quebec City}

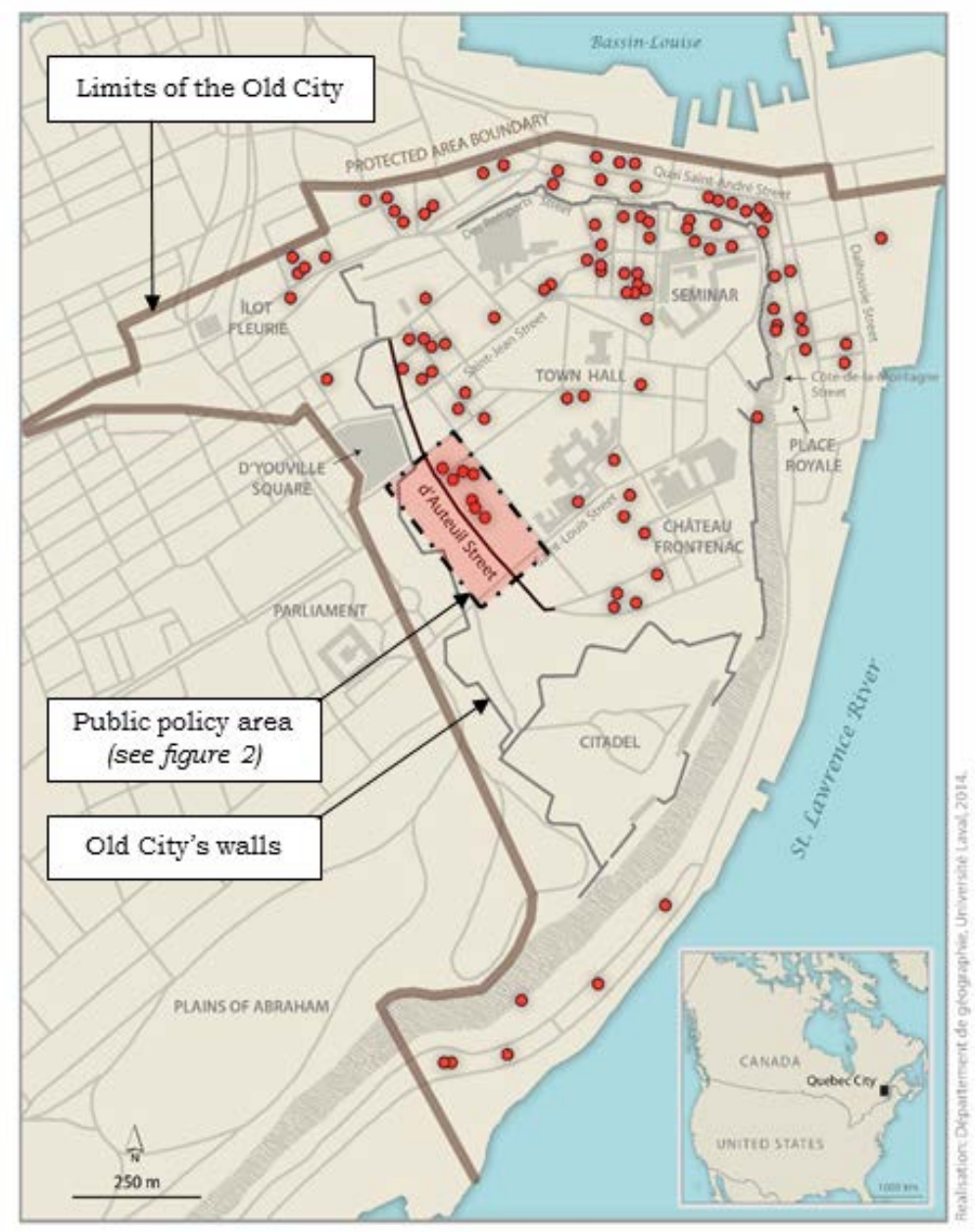

building. In fact, the data reveals that a maximum of 71 transactions have been noted in the same exact location (i.e., in the same building).

A particularity needs to be noted for the 'inside the walls' part of the Old City. First, due to its age, the Old City district's structure of Quebec City is hardly comparable to modern urban structure. While Euclidean distance may be appropriate to represent a form of proximity in most modern North American district configurations, the present case study is composed of dense and winding streets that could affect the notion of proximity. Moreover, historic districts are usually places where walking is valued. For this reason and for comparative purposes, the estimation of the model is based on both Euclidean and network distances. ${ }^{4}$ Euclidean distance can be understood as a direct "as the crow flies" distance while network distance corresponds to the physical walking distance. Second, the location of the street that experiences a change related to the historical policy is located along an urban park and close to the walls. Thus, there are no

\footnotetext{
4 The Euclidean distance $\left(d_{i j}\right)$ is computed using: $d_{i j}=\sqrt{\left(x_{i}-x_{j}\right)^{2}+\left(y_{i}-y_{j}\right)^{2}}$. Where $x$ and $y$ represent the coordinates of the observations $i$ and $j$. The street is considered to be a line and the Euclidean distance can be defined as the shortest path from a particular property to this line. Regarding the network distance, GIS software (ArcMap) is used to compute the shortest road distance between a property and the street.
}

(C) Southern Regional Science Association 2018. 
Figure 3. D’Auteuil Street

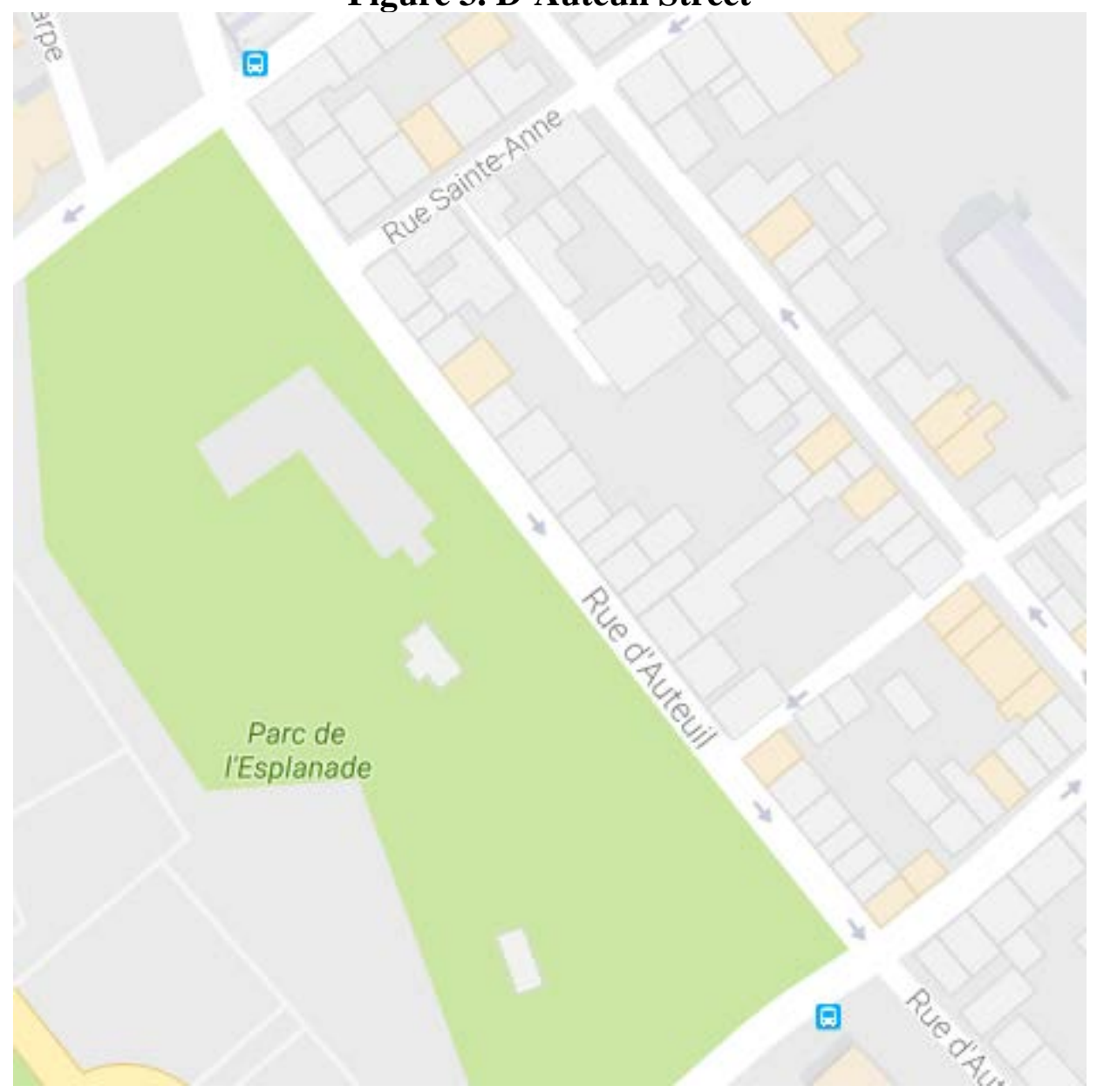

The figure presents the d'Auteuil Street (Rue d'Auteuil) configuration. While residential and commercial buildings occupy the east side of the street, the west side is occupied by an urban park (Parc de l'Esplanade). The park was already present before the street reorganization.

(Source: Google Map, 2016)

transactions that occur on the west side of the street (i.e., there is no building on this side) (Figure 3).

Table 2 presents the spatial distribution of the transactions for the different radiuses used within walking distance from d'Auteuil Street. On the one hand, 184 transactions are included within a 600-meter radius when a network measure of distance is used. The number of transactions occurring before the project was 110, while 74 transactions occurred after. On the other hand, 337 transactions are located in the same radius when the Euclidean measure of distance is chosen, which suggests that both distances express different proximities. Of this total, 203 transactions were recorded before the street renovation and 134 after. This first comparison shows how the network distance captures a more "local" effect by including fewer transactions within the same buffers.

\section{MAIN FINDINGS AND RESULTS}

Considering that the DID estimator is produced using a first difference mathematical transformation, the model is estimated without a constant term, which alters the usual 
Table 2: Spatial Distribution of the Transactions Depending on Proximity to the Renovated Street

\begin{tabular}{|c|c|c|c|c|c|c|c|}
\hline \multirow[b]{2}{*}{$\begin{array}{l}\text { Network } \\
\text { Distance }\end{array}$} & \multicolumn{3}{|c|}{ \# of transactions } & \multirow[b]{2}{*}{$\begin{array}{l}\text { Euclidean } \\
\text { Distance }\end{array}$} & \multicolumn{3}{|c|}{ \# of transactions } \\
\hline & All & Before & After & & All & Before & After \\
\hline $0-150 \mathrm{~m}$ & 43 & 22 & 21 & $0-150 \mathrm{~m}$ & 47 & 26 & 21 \\
\hline $150-300 \mathrm{~m}$ & 55 & 38 & 17 & $150-300 \mathrm{~m}$ & 89 & 58 & 31 \\
\hline $300-450 \mathrm{~m}$ & 49 & 30 & 19 & $300-450 \mathrm{~m}$ & 74 & 47 & 27 \\
\hline $450-600 \mathrm{~m}$ & 37 & 20 & 17 & $450-600 \mathrm{~m}$ & 127 & 72 & 55 \\
\hline$>600 \mathrm{~m}$ & 560 & 368 & 192 & $>600 \mathrm{~m}$ & 407 & 275 & 132 \\
\hline Total & 744 & 478 & 266 & Total & 744 & 478 & 266 \\
\hline
\end{tabular}

interpretation of the R-squared statistic (Wooldridge, 2012; Dubé, Thériault, and Des Rosiers, 2013). For this reason, the performance of the model is assessed using the Akaike Information Criterion (AIC) and the Bayesian Information Criterion (BIC).

The comparison (base) model (Model 1, Table 3) is estimated using only the quarterly dummy variables composing the evolution of nominal price between 1997 and 2011. Here, the only information taken into account are changes in price appreciation related to the fact that buildings and apartments have undergone renovations. The results show that the prices more than doubled within a decade (i.e., between 2003 and 2011). However, price appreciation is not statistically linked to the fact that owners have received a grant for undertaking some renovations between the time of the sale and the resale.

The second and third models are extensions of the base model, adding spatial variables capturing the effect of the historical policy work depending on the proximity to d'Auteuil Street and the moment of the transaction (sale before and resale after street renovations). Since the equation deals with first differences, there is no need to include information on all other intrinsic and extrinsic amenities if these do not change over time. This largely reduces the number of independent variables in the models, while adequately controlling for these aspects using the first difference transformation of the DID estimator hedonic price equation.

In the second model, network distance is used to measure the proximity to the policytargeted portion of the street, while the third model uses network distances. The new specification has AIC and BIC statistics, suggesting that the additional variables increase the quality of the model. According to the coefficients associated with the spatial variables, the price variation of units located within 0 and 150 meters of d'Auteuil Street (0 to 150 meters, network distance) is not influenced by the landscaping policy. However, a significant effect is observed for the two following zones (150 to 300 meters and 300 to 450 meters), while the effect is not significant over 450 meters. For the two significant radiuses, the results suggest a price depreciation varying between CAD $\$ 13,432$ and CAD $\$ 10,812$, respectively, as compared to the more distant properties.

The third model is estimated using a similar specification, but with Euclidean distancebased buffers. According to the lowered BIC and AIC statistics, the model quality is again improved compared to Model 1. As observed in the previous specification, properties located within 150 meters of the street do not experience a significant price shift related to the renovation of the street. However, for properties located within 150 and 300 meters, a negative and 
significant effect is noted. In contrast to the network distance variables, the significant effect is limited to the second buffer when Euclidean distance is used and corresponds to a CAD\$11,268 price decrease, a comparable impact on the previous specification.

Table 3: Estimation Results

\begin{tabular}{|c|c|c|c|c|c|c|}
\hline \multirow[b]{2}{*}{ Independent Variables } & \multicolumn{2}{|c|}{ Model (1) } & \multicolumn{2}{|c|}{ Model (2) } & \multicolumn{2}{|c|}{ Model (3) } \\
\hline & Coef. & Sig. & Coef. & Sig. & Coef. & Sig. \\
\hline $1997-Q 2$ & reference & & reference & & reference & \\
\hline 1997-Q3 & -0.2288 & & -0.2385 & & -0.2299 & \\
\hline 1997-Q4 & 0.5699 & $* * *$ & 0.5566 & $* * *$ & 0.5608 & $* * *$ \\
\hline 1998-Q1 & -0.5747 & $* *$ & -0.5879 & $* *$ & -0.5826 & $* *$ \\
\hline 1998-Q2 & -0.0553 & & -0.0752 & & -0.0713 & \\
\hline 1998-Q3 & -0.0183 & & -0.0479 & & -0.0453 & \\
\hline 1998-Q4 & 0.0503 & & 0.0254 & & 0.0340 & \\
\hline 1999-Q1 & 0.0686 & & 0.0196 & & 0.0192 & \\
\hline 1999-Q2 & 0.1000 & & 0.0627 & & 0.0690 & \\
\hline 1999-Q3 & 0.0303 & & 0.0210 & & 0.0208 & \\
\hline 1999-Q4 & 0.1623 & & 0.1242 & & 0.1351 & \\
\hline 2000-Q1 & 0.1597 & & 0.1397 & & 0.1463 & \\
\hline 2000-Q2 & 0.0783 & & 0.0675 & & 0.0660 & \\
\hline 2000-Q3 & 0.1142 & & 0.1130 & & 0.1129 & \\
\hline 2000-Q4 & 0.1507 & & 0.1292 & & 0.1434 & \\
\hline 2001-Q1 & 0.1242 & & 0.0999 & & 0.1142 & \\
\hline 2001-Q2 & 0.1082 & & 0.0884 & & 0.0909 & \\
\hline 2001-Q3 & 0.1863 & & 0.1611 & & 0.1826 & \\
\hline 2001-Q4 & 0.1813 & & 0.1626 & & 0.1709 & \\
\hline 2002-Q1 & 0.2496 & & 0.2309 & & 0.2354 & \\
\hline 2002-Q2 & 0.3019 & * & 0.2969 & $*$ & 0.3000 & $*$ \\
\hline 2002-Q3 & 0.2132 & & 0.1955 & & 0.2072 & \\
\hline 2002-Q4 & 0.3549 & $* *$ & 0.2879 & $*$ & 0.3142 & $*$ \\
\hline 2003-Q1 & 0.2500 & & 0.2431 & & 0.2505 & \\
\hline 2003-Q2 & 0.5753 & $* * *$ & 0.5585 & $* * *$ & 0.5674 & $* * *$ \\
\hline 2003-Q3 & 0.3297 & $*$ & 0.2783 & $*$ & 0.2904 & $*$ \\
\hline 2003-Q4 & 0.6495 & $* * *$ & 0.6340 & $* * *$ & 0.6331 & $* * *$ \\
\hline 2004-Q1 & 0.4444 & $* * *$ & 0.4320 & $* * *$ & 0.4328 & $* * *$ \\
\hline 2004-Q2 & 0.5782 & $* * *$ & 0.5693 & $* * *$ & 0.5823 & $* * *$ \\
\hline 2004-Q3 & 0.5748 & $* * *$ & 0.5434 & $* * *$ & 0.5683 & $* * *$ \\
\hline 2004-Q4 & 0.6266 & $* * *$ & 0.6094 & $* * *$ & 0.6181 & $* * *$ \\
\hline 2005-Q1 & 0.6875 & $* * *$ & 0.6722 & $* * *$ & 0.6814 & $* * *$ \\
\hline 2005-Q2 & 0.6989 & $* * *$ & 0.6855 & $* * *$ & 0.6922 & $* * *$ \\
\hline 2005-Q3 & 0.7318 & $* * *$ & 0.7406 & $* * *$ & 0.7152 & $* * *$ \\
\hline
\end{tabular}

(c) Southern Regional Science Association 2018. 
Table 3 (Continued)

\begin{tabular}{|c|c|c|c|c|c|c|}
\hline \multirow[b]{2}{*}{ Independent Variables } & \multicolumn{2}{|c|}{ Model (1) } & \multicolumn{2}{|c|}{ Model (2) } & \multicolumn{2}{|c|}{$\underline{\text { Model (3) }}$} \\
\hline & Coef. & Sig. & Coef. & Sig. & Coef. & Sig. \\
\hline $2005-Q 4$ & 0.6736 & $* * *$ & 0.6771 & $* * *$ & 0.6647 & $* * *$ \\
\hline 2006-Q1 & 0.6978 & $* * *$ & 0.7290 & $* * *$ & 0.7047 & $* * *$ \\
\hline 2006-Q2 & 0.6741 & $* * *$ & 0.6681 & $* * *$ & 0.6591 & $* * *$ \\
\hline 2006-Q3 & 0.7554 & $* * *$ & 0.7540 & $* * *$ & 0.7331 & $* * *$ \\
\hline 2006-Q4 & 0.7701 & $* * *$ & 0.7803 & $* * *$ & 0.7594 & $* * *$ \\
\hline 2007-Q1 & 0.8387 & $* * *$ & 0.8398 & $* * *$ & 0.8070 & $* * *$ \\
\hline 2007-Q2 & 0.8567 & $* * *$ & 0.8792 & $* * *$ & 0.8712 & $* * *$ \\
\hline 2007-Q3 & 0.8403 & $* * *$ & 0.8573 & $* * *$ & 0.8271 & $* * *$ \\
\hline 2007-Q4 & 0.9031 & $* * *$ & 0.9078 & $* * *$ & 0.9005 & $* * *$ \\
\hline 2008-Q1 & 0.8385 & $* * *$ & 0.8540 & $* * *$ & 0.8377 & $* * *$ \\
\hline 2008-Q2 & 0.9492 & $* * *$ & 0.9573 & $* * *$ & 0.9276 & $* * *$ \\
\hline 2008-Q3 & 1.0158 & $* * *$ & 1.0422 & $* * *$ & 1.0145 & $* * *$ \\
\hline 2008-Q4 & 0.9313 & $* * *$ & 0.9123 & $* * *$ & 0.8963 & $* * *$ \\
\hline 2009-Q1 & 0.7928 & $* * *$ & 0.7868 & $* * *$ & 0.7669 & $* * *$ \\
\hline 2009-Q2 & 0.8729 & $* * *$ & 0.8946 & $* * *$ & 0.8788 & $* * *$ \\
\hline 2009-Q3 & 0.8376 & $* * *$ & 0.8351 & $* * *$ & 0.8054 & $* * *$ \\
\hline 2009-Q4 & 1.0667 & $* * *$ & 1.0831 & $* * *$ & 1.0760 & $* * *$ \\
\hline 2010-Q1 & 0.9712 & $* * *$ & 0.9812 & $* * *$ & 0.9726 & $* * *$ \\
\hline 2010-Q2 & 1.1202 & $* * *$ & 1.1241 & $* * *$ & 1.1060 & $* * *$ \\
\hline 2010-Q3 & 0.9001 & $* * *$ & 0.9329 & $* * *$ & 0.9170 & $* * *$ \\
\hline 2010-Q4 & 1.1378 & $* * *$ & 1.1314 & $* * *$ & 1.1238 & $* * *$ \\
\hline 2011-Q1 & 1.1329 & $* * *$ & 1.1350 & $* * *$ & 1.1015 & $* * *$ \\
\hline 2011-Q2 & 1.0868 & $* * *$ & 1.0993 & $* * *$ & 1.0848 & $* * *$ \\
\hline 2011-Q3 & 1.3397 & $* * *$ & 1.5400 & $* * *$ & 1.5564 & $* * *$ \\
\hline Grant for renovations (dummy) & 0.0386 & & 0.0231 & & 0.0202 & \\
\hline Impact - distance to d'Auteuil Street & & & & & & \\
\hline Network dist., 0 to 150 m (Buffer) & & & -0.0405 & & & \\
\hline Network dist., 150 to 300 m (Buffer) & & & -0.2952 & $* *$ & & \\
\hline Network dist., 300 to 450 m (Buffer) & & & -0.2376 & $*$ & & \\
\hline Network dist., 450 to 600 m (Buffer) & & & 0.1353 & & & \\
\hline Network dist., over 600 m & & & reference & & & \\
\hline Euclidean dist., 0 to 150 m (Buffer) & & & & & 0.0102 & \\
\hline Euclidean dist., 150 to 300 m (Buffer) & & & & & -0.2476 & $* *$ \\
\hline Euclidean dist., 300 to 450 m (Buffer) & & & & & 0.0883 & \\
\hline Euclidean dist., 450 to 600 m (Buffer) & & & & & 0.0795 & \\
\hline Euclidean dist., over 600 m & & & & & reference & \\
\hline
\end{tabular}

(c) Southern Regional Science Association 2018. 
Table 3 (Continued)

\begin{tabular}{|c|c|c|c|}
\hline \multirow[b]{2}{*}{ Independent Variables } & Model (1) & Model (2) & Model (3) \\
\hline & Coef. Sig. & Coef. Sig. & Coef. Sig. \\
\hline$N$ & 744 & 744 & 744 \\
\hline$R^{2}$ & 0.575 & 0.586 & 0.585 \\
\hline Akaike Information Criteria (AIC) & 692.977 & 682.129 & 683.867 \\
\hline Baysian Information Criteria (BIC) & 960.475 & 968.075 & 969.813 \\
\hline
\end{tabular}

Legend: ${ }^{*} \mathrm{p}<0,05 ; * * \mathrm{p}<0,01 ; * * * \mathrm{p}<0,001$

Overall, the results point to three main conclusions. First, the assistance programs for renovations of properties located in Old Quebec have no impact on the selling price variations. This does not mean that condominium renovations are not valued. It is conceivable that renovated condominiums are sold at higher prices, meaning that public funds used for private renovations would be transformed in a greater profit margin for the seller and to tax revenues for the municipality. However, this is not the case here. One assumption would be that such renovations remove some "cachet" from the original apartments, even when offering some additional and more contemporaneous commodities. Another assumption would be that the effect is minimized considering that most of the condominiums in the area had been restored a few years before the analysis. In fact, as previously mentioned, two-thirds of the condominiums had been restored between 1980 and 1999. A final assumption, that could not be tested here, is that renovation may influence time-on-the-market, but not prices, with renovated condominiums being sold more rapidly than the others.

Second, the results suggest a localized and negative effect of the landscaping renovation of d'Auteuil Street for condominiums located within 150 to 450 meters network distance and within 150 to 300 meters Euclidian distance. As a matter of fact, the reorganization and landscaping of d'Auteuil Street, turning from a four-lane street into a two-lane street, has brought more road traffic to the adjacent streets of the district. The reorganization of the street into a oneway road leading south also added high traffic volume in the heart of the historic district (more than 400 vehicles every hour from 7-9 am and 3-5 pm on work days). Noise can also be generated from the change in the material used to build the road, a result of the pavement of the road itself (made of stones, not of asphalt) on which vehicles travel up to $50 \mathrm{~km} / \mathrm{h}(31 \mathrm{~m} / \mathrm{h}){ }^{5}$ Unlike asphalted roads, a paved road generates an uneven friction between the car wheels and the ground, generating more noise. Consequently, the additional crowding effect and noise pollution can negatively influence house prices. Several studies have already shown how noise can lead to a depreciation of residential values, as such might be the case with airports and housing values (Baranzini and Ramirez, 2005; Cohen and Coughlin, 2008).

Another negative externality could be related to the redesigned location of parking spaces. Surrounding streets may experience the drawback of the new street design since parking spaces are limited for residents inside the walled section of the Old City. In fact, the new oneway street may also change parking habits for vehicles heading north. This assumption seems plausible considering the scarcity of parking spaces in such dense and winding areas.

\footnotetext{
${ }^{5}$ Sandberg (1987) has investigated the issue of road traffic noise in regard to different surface components, namely stones and asphalt.
}

(c) Southern Regional Science Association 2018. 
Although the closest properties should be more influenced by the renovation work, no significant effect is noticeable in their resale price. This suggests that for the closest properties the positive externalities attributed to heritage factors, such as discursive policy objectives and visual aspect (the landscaping work and the addition of vegetation, as well as the construction of larger sidewalks), can counterbalance the negative externalities. In fact, one can assume that the new vegetation could only have a minor impact since most of it is added on the west side of the street, where an urban park was already present. The condominiums, therefore, do not benefit much from the plant cover (noise reduction, intimacy, shade). Interestingly, a minimized impact of vegetation would support the presence of a positive impact of intangible heritage factors. Yet, these valued elements would be strongly localized. However, the expanded sidewalk and the new monuments are located on the west side of the street (opposite side of the buildings). The new noisy and busy street organization is then close to the residential properties.

Third, the stability of the results by using two different definitions of the proximity confirms the pattern. According to the descriptive statistics, the use of network distance presents a more concentrated distribution of the observations between distance radiuses and a more "local" definition of proximity. In fact, most of the observations identified in a 300 to 450 meter network distance buffer are located in the 150 to 300 meter Euclidean distance buffer. The fact that both results return similar conclusions gives an interesting robustness check. The results suggest a price depreciation varying between CAD\$13,432 and CAD\$10,812. ${ }^{6}$

\section{CONCLUSION}

Designated by law as a protected area and listed on the UNESCO World Heritage List, the historic district of Old Quebec is an important realm of memory, not only for the people of Quebec, but also for North America. As part of a patrimonialization approach, heritage policies help to maintain and support a cultural and ideological heritage that may be transposed to residential values through location factors and proximity effects. Previous studies have concluded that both heritage or cultural factors and location in an old city district are valued by the residential market. The heritage dimension of a patrimonialization approach could be expected to be an intangible source of positive externalities. However, while heritage policies are implemented in an old city district with non-concealed expectations regarding symbolism development, no previous work had attempted to assess their impacts on property values. The process of historic designation, well considered by scholars and generally valued, should be considered as a framework for upcoming policies. In a dynamic and temporal perspective, future policies could enhance or overbalance the designation economic impacts. Moreover, intangible heritage policy expectations could even be a trade-off for economic impacts.

This paper explores the impact of a particular heritage policy implemented in an old city context: the reorganization of d'Auteuil Street, located in the designated Old Quebec City district, with a heritage policy transforming the landscape of the street in 2005. The impact is estimated based on the hedonic pricing theory, using information on the property final sale price for condominiums sold between 1997 and 2011. A repeated sales approach based on a difference-in-differences (DID) estimator is applied to isolate the effect of proximity to the

\footnotetext{
${ }^{6}$ Additional robustness tests have been performed using continuous distances and applying an inverse distance function as well as a negative exponential function. In both cases, the coefficient associated with the distance is not significant. These results can be explained by the non-linear decay functions applying larger weights to the closest observations not affected by the change. This test using continuous distance also confirms the choice of buffers for a more precise measurement in this particular case.
}

(C) Southern Regional Science Association 2018. 
considered street while controlling for the impact of constant extrinsic and intrinsic propertyrelated factors.

While positive effects could be expected due to heritage and landscaping factors, the results underline a different story. Based on two different definitions of proximity to the street, network distance and Euclidean distance, the results show no significant positive effect for condominiums located in the direct proximity (along the street) of d'Auteuil Street, and negative impact for properties located close to the street. Estimation results also outline that both distance definitions show similar and, therefore, robust results. Yet, the network distance appears to be a more precise and appropriate definition of proximity in such a context.

The fact that no positive, significant difference is noticed before and after the renovations for immediate proximity properties ( 0 to 150 meters) does not mean that the proximity to d'Auteuil Street is not valued. It only means that renovations do not, generally speaking, bring a positive net plus-value to the condominium real estate market. We can, therefore, reasonably assume that the improvement generates a situation where the positive externalities (physical and intangible changes) are completely outweighed by the negative externalities, at least in this particular real estate market. In other words, from the residential market perspective the positive expected impacts of the heritage policy in terms of patrimonialization and symbolic construction could be cancelled by physical landscaping decisions. The negative impact on greater distance properties may be explained by a set of negative externality drawbacks associated with a spatial spillover effect triggered by the landscaping and urban reorganization decisions.

Of course, the global economic impact of the renovation of the street clearly depends on other factors, such as the tourism effect and impact on commercial properties, which are not accounted for here. The calculation of the total economic impact of such heritage policies should not be simplified to only the condominium market. However, the results show that developing places that attract more people and generate more noise may induce some cost for the local resident, as measured by the house price decrease. Overall, such negative effect needs to be relativized, but clearly underlines the potential collateral negative effect related to heritage landscape policies.

Ultimately, even if the analysis is limited to one particular case study, the results suggest that heritage conservation policies are complex in nature due to the equilibrium between intangible and physical landscaping dimensions. In fact, this suggests that any heritage policy implemented in a historic district context cannot be taken separately from the general urban context and development strategies. In such a situation, policy makers and planners should be aware that the expected economic impacts could vary from the traditional perspective. An expected return on investment for the municipality through higher residential tax income would then be arguable. In the actual case, the observed decreasing property values suggest that landscaping strategies are not profitable in the long term, at least from the residential property tax viewpoint. It should be mentioned that the expected economic impacts of such heritage policies may not only affect tourism, and possible interrelations between economic residential impacts and tourism impacts remain to be explored. Moreover, since heritage policies are not isolated, future implementations in the Old City area could affect the overall expected impacts over time. In other terms, this case study shows that heritage in a historic district is by no means cast in stone. The vocation given to the historic district can change over the years. Hence, heritage policies are dynamic variables hedonic modeling has to turn to. 


\section{REFERENCES}

Ahlfeldt, Gabriel M. and Wolfgang Maennig. (2010) "Substitutability and Complementarity of Urban Amenities: External Effects of Built Heritage in Berlin,” Real Estate Economics, 38(2), 285-323. doi: 10.1111/j.1540-6229.2010.00268.x

Asabere, Paul K., and Forrest E. Huffman. (1991) "Zoning and industrial land values: the case of Philadelphia,” Real Estate Economics, 19(2), 154-160

Asabere, Paul K., Forrest E. Huffman, and Seyed Mehdian. (1994) “The Adverse Impacts of Local Historic Designation: The Case of Small Apartment Buildings in Philadelphia,” Journal of Real Estate Finance and Economics, 8(3), 225-234.

Asabere, Paul K. and Forrest E. Huffman. (1997) "Hierarchical Zoning, Incompatible Uses and Price Discounts,” Real Estate Economics, 25(3), 439.

Baranzini, Andrea and José V. Ramirez. (2005). "Paying for Quietness: The Impact of Noise on Geneva Rents,” Urban Studies, 42(4), 633-646.

Berthold, Étienne. (2012a) Les Quartiers Historiques: Pressions, Enjeux, Actions. Laval University Press: Quebec, Qc.

Berthold, Étienne. (2012b) Patrimoine, Culture et Mise en Récit: l'Île d'Orléans et la Place Royale de Québec. Laval University Press: Quebec, Qc.

Case, Karl E. and Robert J. Shiller. (1987) "Prices of Single-Family Homes Since 1970: New Indexes for Four Cities,” NBER Working Papers 2393, National Bureau of Economic Research.

Case, Karl E. and Robert J. Shiller. (1989) “The Efficiency of the Market for Single-Family Homes,” American Economic Review, 79(1), 125-137.

Clark, David E. and William E. Herrin. (1997) "Historical Preservation Districts and Home Sale Prices: Evidence From the Sacramento Housing Market,” Review of Regional Studies, 27(1), 29-48.

Coffin, Donald A. (1989) “The Impact of Historic Districts on Residential Property Values,” Eastern Economic Journal, 15(3), 221-228.

Cohen, Jeffrey P. and Cletus C. Coughlin. (2008) "Spatial Hedonic Models of Airport Noise, Proximity, and Housing Prices,” Journal of Regional Science, 48(5), 859-878.

Coulson, Edward N. and Robin M. Leichenko. (2001) “The Internal and External Impact of Historical Designation on Property Values,” Journal of Real Estate Finance and Economics, 23(1), 113-124.

Dubé, Jean, François Des Rosiers, Marius Thériault, and Patricia Dib. (2011) "Economic Impact of a Supply Change in Mass Transit in Urban Areas: A Canadian Example," Transportation Research Part A: Policy and Practice, 45(1), 46-62.

Dubé, Jean and Diego Legros. (2014) "Spatial Econometrics and the Hedonic Pricing Model: What About the Temporal Dimension?,” Journal of Property Research, 31(4), 333-359.

Dubé, Jean, Marius Thériault, and François Des Rosiers. (2013) “Commuter Rail Accessibility and House Values: The Case of the Montreal South Shore, Canada, 1992-2009," Transportation Research Part A: Policy and Practice, 54, 49-66.

c Southern Regional Science Association 2018. 
Foucault, Michel. (1969) L’Archéologie du Savoir. Gallimard: Paris.

Gatzlaff, Dean H. and Donald R. Haurin. (1997) "Sample Selection Bias and Repeat-Sales Index Estimates,” Journal of Real Estate Finance and Economics, 14(1), 33-50.

Gatzlaff, Dean H. and Donald R. Haurin. (1998) "Sample Selection and Biases in Local House Value Indices,” Journal of Urban Economics, 43(2), 199-222.

Gibbons, Stephen and Stephen Machin. (2008) "Valuing School Quality, Better Transport, and Lower Crime: Evidence From House Prices,” Oxford Review of Economic Policy, 24(1), 99-119.

Graham, Brian, Graham J. Ashworth, and John E. Tunbridge. (2000) A Geography of Heritage: Power, Culture and Economy. Arnold: London.

Greffe, Xavier. (2003) La Valorisation Économique du Patrimoine. La Documentation Française: Paris.

Harrison, Rodney. (2013) Heritage: Critical Approaches. Routledge: London.

Heintzelman, Martin D. and Jason A. Altieri. (2013) “Historic Preservation: Preserving Value?," Journal of Real Estate Finance and Economics, 46(3), 543-563.

Hobsbawm, Eric and Terence Ranger. (1983) The Invention of Tradition. Cambridge University Press: Cambridge.

Lazrak, Faroek, Peter Nijkamp, Piet Rietveld, and Jan Rouwendal. (2014) "The Market Value of Cultural Heritage in Urban Areas: An Application of Spatial Hedonic Pricing,” Journal of Geographical Systems, 16(1), 89-114.

Leichenko, Robin M., Edward N. Coulson, and David Listokin. (2001) "Historic Preservation and Residential Property Values: An Analysis of Texas Cities,” Urban Studies, 38(11), 1973-1987.

Mason, Randall. (2005) Economics and Historic Preservation. In T. B. Institution (Ed.). Metropolitan Policy Program: Washington, DC.

McMillen, Daniel P. (2010) “Issues in Spatial Data Analysis,” Journal of Regional Science, 50(1), 119-141.

Morisset, Lucie K. (2009) Des Régimes d'Authenticité: Essai sur la Mémoire Patrimoniale. University of Quebec Press: Québec, Qc.

Moro, Mirko, Karen Mayor, Seán Lyons, and Richard S.J. Tol. (2013) "Does the Housing Market Reflect Cultural Heritage? A Case Study of Greater Dublin,” Environment and Planning A, 45(12), 2884-2903.

Narwold, Andrew, Jonathan Sandy, and Charles Tu. (2008) "Historic Designation and Residential Property Values,” International Real Estate Review, 11(1), 83-95.

Noonan, Douglas S. (2007) "Finding an Impact of Preservation Policies: Price Effects of Historic Landmarks on Attached Homes in Chicago, 1990-1999," Economic Development Quarterly, 21(1), 17-33.

Rickman, Dan S. (2009) "Neighborhood Historic Preservation Status and Housing Values in Oklahoma County, Oklahoma,” Journal of Regional Analysis and Policy, 39(2), 99-108. 
Rosen, Sherwin. (1974) "Hedonic Prices and Implicit Markets: Product Differentiation in Pure Competition,” Journal of Political Economy, 82(1), 34-55.

Roy, Sudipto, Jason Byrne, and Catherine Pickering. (2012) “A Systematic Quantitative Review of Urban Tree Benefits, Costs, and Assessment Methods Across Cities in Different Climatic Zones,” Urban Forestry \& Urban Greening, 11(4), 351-363.

Ryberg-Webster, Stephanie and Kelly L. Kinahan. (2014) "Historic Preservation and Urban Revitalization in the Twenty-First Century,” Journal of Planning Literature, 29(2), 119139.

Saint-Pierre, Diane. (2008) “Identité et Patrimoine... Deux Notions au Cœur des Interventions Patrimoniales Publiques du Québec et du Canada.” In Nemery, Jean-Claude, Michel Rautenberg, and Fabrice Thuriot, Stratégies Identitaires de Conservation et de Valorisation du Patrimoine. L'Harmattan: Paris, 115-124.

Sandberg, Ulf. (1987) "Road traffic noise-the influence of the road surface and its characterization.” Applied Acoustics, 21(2), 97-118.

Sander, Heather, Stephen Polasky, and Robert G. Haight. (2010) “The Value of Urban Tree Cover: A Hedonic Property Price Model in Ramsey and Dakota Counties, Minnesota, USA,” Ecological Economics, 69(8), 1646-1656.

Van Duijn, Mark and Jan Rouwendal. (2013) "Cultural Heritage and the Location Choice of Dutch Households in a Residential Sorting Model,” Journal of Economic Geography, 13(3), 473-500.

Wooldridge, Jeffrey. (2012) Introductory Econometrics: A Modern Approach. Cengage Learning: Boston, MA.

Zahirovic-Herbert, Velma and Swarn Chatterjee. (2012) "Historic Preservation and Residential Property Values: Evidence From Quantile Regression,” Urban Studies, 49(2), 369-382.

Zukin, Sharon. (1996) The Cultures of Cities. Wiley-Blackwell: Malden, MA. 